\title{
Spirituality and meaning of life in nursing education: report of experience in teaching
}

\author{
Espiritualidade e sentido da vida na educação em enfermagem: relato de experiência no ensino
}

Espiritualidad y sentido de la vida en la educación en enfermería: relato de experiencia en la enseñanza

\section{Angelica Yolanda Bueno Bejarano Vale de Medeiros' ORCID: 0000-0001-9061-4476 \\ Eliane Ramos Pereira ORCID: 0000-0002-6381-3979 \\ Rose Mary Costa Rosa Andrade Silva' ORCID: 0000-0002-4310-8711 \\ Renata Carla Nencetti Pereira Rocha' ORCID: 0000-0003-1053-6231 \\ Elisabete Correa Vallois' ORCID: 0000-0002-5534-1270 \\ Diva Cristina Morett Romano Leão ORCID: 0000-0002-2923-0630}

'Universidade Federal Fluminense. Niterói, Rio de Janeiro, Brazil.

How to cite this article: Medeiros AYBBV, Pereira ER, Silva RMCRA, Rocha RCNP Vallois EC, Leão DCMR. Spirituality and meaning of life in nursing education: report of experience in teaching.

Rev Bras Enferm. 2020;73(2):e20180554. doi: http://dx.doi.org/10.1590/0034-7167-2018-0554

Corresponding Author: Angelica Yolanda Bueno Bejarano Vale de Medeiros E-mail: angelicaflow@gmail.com

EDITOR IN CHIEF: Dulce Aparecida Barbosa ASSOCIATE EDITOR: Maria Saraiva

Submission: 07-09-2018

Approval: 01-28-2019

\section{ABSTRACT}

Objectives: To report the experience in teaching internship in the elective discipline "Spirituality in the Health Field" of the curriculum of the graduation course in Nursing of Universidade Federal Fluminense. Methods: This is a case report with descriptive-reflexive approach of the class "the meaning of life as spiritual care strategy in the nursing practice". For the elaboration of the discipline, a lesson plan and active methodologies were used. Results: The strategy used for preparation of the class allowed transmitting and constructing knowledge objectively. The reflections disclosed along with students showed the importance of the meaning of life as spiritual care in nursing practices for the health professional and for the act of being cared for. Final considerations: The class was considered a successful experience, as the theme proposed was essential for the theoretical-reflective construction about spirituality and meaning of life as a form of care that transcends technical procedures. Descriptors: Teaching; Spirituality; Nursing Education; Nursing Care; Quality of Life.

\section{RESUMO}

Objetivos: Relatar a experiência em estágio-docência na disciplina optativa"Espiritualidade no Campo da Saúde" da grade curricular da graduação em Enfermagem da Universidade Federal Fluminense. Métodos: Trata-se de um relato de experiência de abordagem descritivo-reflexiva da aula "o sentido da vida como estratégia de cuidado espiritual na prática da enfermagem". Para a construção do curso foi utilizado um plano de aula e metodologias ativas. Resultados: A estratégia utilizada na elaboração da aula possibilitou a transmissão e construção do conhecimento de forma objetiva. As reflexões desveladas com alunos evidenciaram a importância do sentido da vida como cuidado espiritual nas práxis da enfermagem para o profissional da saúde e para o ser cuidado. Considerações finais: A aula foi considerada uma experiência exitosa, na medida que o tema proposto foi fundamental para a construção teórico-reflexiva acerca da espiritualidade e sentido da vida como forma de cuidado que transcende os procedimentos técnicos.

Descritores: Ensino; Espiritualidade; Educação em Enfermagem; Cuidados de Enfermagem; Qualidade de Vida.

\section{RESUMEN}

Objetivos: Relatar la experiencia en prácticas-docencia en la asignatura electiva "Espiritualidad en el ámbito de la salud" del plan de estudios del grado en Enfermería de la Universidad Federal Fluminense. Métodos: Se trata de un relato de experiencia de enfoque descriptivo-reflexivo de la clase "el sentido de la vida como estrategia de cuidado espiritual en la práctica de la enfermería". Para la elaboración del curso, se utilizó un plan de clase y metodologías activas. Resultados: La estrategia utilizada en la elaboración de la clase permitió la transmisión y construcción del conocimiento de forma objetiva. Las reflexiones desveladas con los alumnos evidenciaron la importancia del sentido de la vida como cuidado espiritual en las praxis de la enfermería para el profesional de la salud y para el ser cuidado. Consideraciones finales: la clase fue considerada una experiencia exitosa, en la medida en que el tema propuesto fue fundamental para la construcción teórico-reflexiva acerca de la espiritualidad y el sentido de la vida como forma de cuidado que transciende los procedimientos técnicos.

Descriptores: Enseñanza; Espiritualidad; Educación en Enfermería; Cuidados de Enfermería; Calidad de Vida. 


\section{INTRODUCTION}

Academic master's students of the multidisciplinary program in Health Care Sciences (PACCS) of the nursing school Aurora de Alfonso Costa, of Universidade Federal Fluminense (UFF), in Niterói, Rio de Janeiro, Brazil, can participate in the praxis of academic teaching as guest lecturers in the curriculum of the undergraduate nursing course from the same institution, depending on the theme of the ongoing project of the master's student and his/her specialization. As a psychologist and student of the master's course, I conduct a research focused on cancer patients, addressing the theme "meaning of life" (ML) from the perspective of the logotherapy by the psychiatrist and neurologist Viktor Emil Frankl (1905-1997), an approach considered the third Viennese school of psychotherapy, being very influent internationally. This approach, whose roots are phenomenological, view human as a spiritual being, a dimension that includes the possibility of being free and responsible and continually seeking the meaning of life ${ }^{(1)}$.

Spirituality is also considered a set of all emotions, nonmaterial convictions, with the supposition that life is more than what one can realize or fully understand, referring to issues such as the sense and meaning of life, without limiting to any particular type of belief or religious practice ${ }^{(2)}$.

The spiritual dimension has been exploited in several studies of the health care field in the $21^{\text {st }}$ century, and one of the characteristics of this care includes, among others, the therapeutic intervention focused on the meaning ${ }^{(3)}$, which acts as a motor to face the challenges that life itself poses, especially those related to human suffering ${ }^{(1)}$. In this respect, studying $M L$ in the health field can be very important; especially in nursing, a profession that deals with pain, suffering and death.

Therefore, addressing the ML is a form of spiritual, holistic and humane care, both for the health professional and for the praxis with the person to be cared for. This perspective represents a motivation for the nursing profession, satisfying the needs, desires and personal interests ${ }^{(4)}$, an openness to inner transformation, personal development and, consequently, improvement in their care practices ${ }^{(5)}$, whereas for patients, an alternative of care beyond the biological and psychological, allowing better adjustments to treatment, positive perspectives of the future and mainly improved quality of life ${ }^{(6)}$.

The ML has already been used as a strategy in the spiritual care practice. Nurses working in Oncology, Geriatrics and Pediatrics recognize the importance of addressing this dimension with their patients, since this care promotes the healing of the latter and the nurses' spiritual experience ${ }^{(3)}$. Joyce Travelbee (1926-1973) was one of the internationally recognized nurses who explored this methodology. Influenced by Viktor Frankl's psychotherapeutic approach, she proposed that doctors and nurses help their patients to unveil the sense and meaning of life ${ }^{(7)}$.

Travelbee is known for her interpersonal theory, consisting of a nurse-patient relationship, so that the professional is available to help in meeting the needs of the person cared for, aiming at offering this strategy to face the situation of suffering, seizing knowledge from it and facilitating its meaning; thus, the nursingpatient relationship transcends the technical purposes of health practices, becoming a more reciprocal relationship ${ }^{(8)}$.
Other evidence on the effectiveness of addressing spirituality and $\mathrm{ML}$ in health are being observed in the results of the projects of the Núcleo de Pesquisa Qualitativa Translacional em Espiritualidade e Emoções na Saúde (Center for Translational Qualitative Research in Spirituality and Emotions in Health) (Qualitees), registered in the directory of the Brazilian National Council for Scientific and Technological Development (CNPq), whose transdisciplinary approach studies affective, spiritual and psychosocial dimensions of human existence and individuals' well-being in the context of health/illness or risk situations. Currently, I contribute to this group through research with cancer patients, using the meaning-centered psychotherapy, addressing the theme of the meaning of life.

This article aims to describe the practice of teaching internship of a psychologist along with the nursing student, addressing the theme of the meaning of life and spirituality from the anthropological perspective of the logotherapy by Viktor Frankl as relevant for the health professional and its influence on the acts of caring and being cared for. As teaching-learning strategy, active methodologies and a lesson plan were used.

\section{OBJECTIVES}

To report the experience in teaching internship in the elective discipline "Spirituality in the Health Field" of the curriculum of the graduation course in Nursing of the Universidade Federal Fluminense.

\section{METHODS}

This is a descriptive-reflective case report of the practice in teaching internship as a psychologist and master's student of the Academic Graduate Program in Health Care Sciences of the UFF, in the elective discipline "Spirituality in the Health Field" of the curriculum of the graduate course in Nursing. The topic was the meaning of life as spiritual care strategy in the practice of nursing, based on the theoretical framework by Viktor Emil Frankl (1905-1997). The class last 2 hours, and 21 nursing students enrolled in the discipline in the second half of 2017 attended it. The discipline was structured through a lesson plan ${ }^{(9)}$, using active methodologies ${ }^{(10)}$, such as: dialogued exposition, recreationalpedagogical dynamics and oral assessment ${ }^{(10)}$.

\section{DEVELOPMENT}

For a better understanding, the lesson plan used, the three stages of the course taught, and the results of the insights and reflections of the teacher and the nursing student in the teaching praxis will be described.

\section{Lesson plan}

It was used as a strategy to systematize knowledge, activities and procedures to be developed along with the student to achieve the objectives proposed ${ }^{(9)}$. The items and content used are described in Chart 1. 
Chart 1 - Template of lesson plan

\begin{tabular}{|c|c|}
\hline Items & Content \\
\hline Theme & $\begin{array}{l}\text { The meaning of life as spiritual care strategy in } \\
\text { the practice of nursing from the perspective of } \\
\text { logotherapy. }\end{array}$ \\
\hline Justification & $\begin{array}{l}\text { Knowledge construction about spirituality from the } \\
\text { anthropological viewpoint of the human being and of } \\
\text { the meaning of life as a key driver for a life of quality. } \\
\text { Identification of the students' meaning of life and of } \\
\text { the reasons for have chosen the profession, and of } \\
\text { how this subject contributes to the praxis of caring. }\end{array}$ \\
\hline $\begin{array}{l}\text { General } \\
\text { objective }\end{array}$ & $\begin{array}{l}\text { To address the topic of spirituality and meaning of } \\
\text { life from the perspective of logotherapy by Viktor } \\
\text { Frankl. }\end{array}$ \\
\hline $\begin{array}{l}\text { Specific } \\
\text { objectives }\end{array}$ & $\begin{array}{l}\text { 1. To reflect on the concept of meaning of life along } \\
\text { with the student and on the reasons for the choice } \\
\text { of the profession. } 2 \text {. To discuss the importance of } \\
\text { the meaning of life as a key driver for a life of quality, } \\
\text { both for the caregiver and for the person cared for. }\end{array}$ \\
\hline $\begin{array}{l}\text { Stages } \\
\text { planned for } \\
\text { the discipline }\end{array}$ & $\begin{array}{l}\text { The 2-hour class was divided into three stages. First: } \\
\text { to address the theme of spirituality and meaning } \\
\text { of life in the philosophical and scientific context; } \\
\text { Second: round of conversation; Third: assessment. }\end{array}$ \\
\hline $\begin{array}{l}\text { Methodology } \\
\text { used }\end{array}$ & $\begin{array}{l}\text { Dialogued exposition using the audiovisual resource } \\
\text { Datashow, the recreational-pedagogical dynamics in } \\
\text { a round of conversation and the oral assessment }{ }^{(9)} \text {. }\end{array}$ \\
\hline Assessment & $\begin{array}{l}\text { Reflection and discussion on the relevance of the } \\
\text { theme for the care practice. }\end{array}$ \\
\hline Bibliography & $\begin{array}{l}\text { Books of theoretical and conceptual framework } \\
\text { and recent international articles were used, as well } \\
\text { as previous experiences and results of the ongoing } \\
\text { studies with cancer patients, developed by the } \\
\text { master's student. }\end{array}$ \\
\hline
\end{tabular}

\section{Stages of the class}

$1^{\text {st }}$ Stage: the active methodology used was the dialogued exposition, which addressed the definition of spirituality and the meaning of life from the anthropological perspective of logotherapy and of recent scientific studies. Dr. Viktor Frankl's experience in concentration camps was recounted, as well as how having a positive view of the future and a meaning of life, despite the suffering, enabled him to survive the horrors of daily life in captivity.

$2^{\text {nd }}$ Stage: active methodology and recreational-pedagogical dynamics in the form of round of conversation were used. Initially, students were asked two questions, to be answered individually, on a blank sheet: 1) What is the meaning of my life? and 2) Why am I here right now? For this activity, students were asked to avoid being distracted by the phone, and an instrumental background music was put on. After four minutes, it was suggested that students willingly discuss the answers. Then, sources or existing ways to unveil the meaning of life were reported to them. At that time, one explained that, according to Frankl's theory, the motivation source for the meaning of life derives from the concretization of values, which are part of human spirituality and are distributed into creative values, experiential values, and attitudinal values.

$3^{\text {rd }}$ Stage: the oral assessment method was used, in which one proposes a reflection and discussion on how the theme meaning of life can contribute to the professional as caregiver and how it could contribute to the patient's spiritual care. At that moment, international studies on the topic were addressed, in addition to the master's student experience of the ongoing study with cancer patients.

\section{RESULTS}

The planning and methodology used allowed transmitting and constructing knowledge objectively. In its turn, perceptions and reflections of the teaching along with the nursing students were recorded during the class and grouped according to the three activities performed:

$1^{\text {st }}$ Stage: in the dialogued exposition, students showed themselves to be attentive as well as interested in spirituality, because the approach used in logotherapy was different from a religious vision. Most of the students clearly did not know the biography of the psychiatrist and neurologist Viktor Emil Frankl and his theory about ML. To report Frankl's experience in concentration camps allowed for the understanding of the importance of the ML of those who live in continuous suffering. In sum, unveiling ones own $\mathrm{ML}$ is a fundamental existential need for humans, and not only a rationalization or a feeling attributed.

$2^{\text {nd }}$ Stage: in the round of conversation, when asked about the meaning of life, several expressions were observed. Some students demonstrated confidence at the time of writing, and others, uncertainty and quietness, without having anything to write on the sheet. Some emotions were expressed, as the crying of some of them and the joy of others. The first people who wanted to share their answers related to the first question "What is the meaning of my life?", stated that their lives had meaning and that they want to achieve future goals related to their profession, whereas other students preferred not to talk. As a psychologist, I was surprised by the emotional reactions of the students who cried, once the questionings aimed to invite them to reflect instead of causing discomfort or exposing the emotions and feelings involved in the particular moment of the student in the classroom. When faced with the crying, I came closer to the students and asked if everything was okay, while some colleagues set themselves to bring water. All answered "yes" and without negative repercussions, the class continued at the pace proposed.

On the other hand, in the second question, "Why am I here right now?", as it was an open question, some understood as the reason why they are studying Nursing, and others, as the reason for being enrolled in that discipline. Among the former, several answers were observed, including: lucky; having passed the entrance exam; life mission to help other people; motivation due to cases of sick relatives; and influence of relatives who are in the health field as well. Those who associated the question with the discipline reported that the choice was made due to the need of meeting the course workload, the possibility of a relationship between the topic spirituality and their personal beliefs and faith, the belief that it is a fundamental issue to be addressed along with the patient.

Therefore, inquiring about the meaning of life and the reasons that lead people to do things promotes a deep reflection and 
proves to be necessary for understanding or justifying their actions and motivations, especially when devoting their lives to others.

$3^{\text {rd }}$ Stage: in the oral assessment, students made three reflections on the importance of ML, described in Chart 2.

Chart 2 - Oral assessment: importance of the meaning of life for the nursing professional

\begin{tabular}{|c|c|}
\hline Reflections & Discussions \\
\hline $\begin{array}{l}1 \text { st "The nurse has a key role } \\
\text { in the patients' well-being, } \\
\text { and the meaning of life can } \\
\text { help in the care provision". }\end{array}$ & $\begin{array}{l}\text { On that thought, the hypotheses } \\
\text { formulated by students were } \\
\text { related to cases in which patients } \\
\text { already received all the technical } \\
\text { care necessary to treat the disease } \\
\text { and, even so, improvement was not } \\
\text { observed, and treating the spiritual } \\
\text { dimension through the meaning of } \\
\text { life becomes an alternative, promoting } \\
\text { well-being at that moment, in the } \\
\text { "right here and right now." }\end{array}$ \\
\hline $\begin{array}{l}2^{\text {nd }} \text { "Discovering and } \\
\text { experiencing that life has a } \\
\text { meaning allows the nurse } \\
\text { to be more sensitive in the } \\
\text { spiritual dimension, which } \\
\text { enables a differentiated } \\
\text { care, transforming the } \\
\text { thought and the attitude } \\
\text { faced with the other's } \\
\text { suffering". }\end{array}$ & $\begin{array}{l}\text { Regarding this reflection, students } \\
\text { stated that knowing the reasons to live } \\
\text { makes all the difference in people's lives, } \\
\text { especially for those who work in a field } \\
\text { in which human suffering is present. } \\
\text { It is a personal opportunity to reflect } \\
\text { that, even in the most difficult moments } \\
\text { of life, there is a light at the end of the } \\
\text { tunnel, being an experience that is part } \\
\text { of human life. What matters most is the } \\
\text { human's attitude faced with suffering. }\end{array}$ \\
\hline $\begin{array}{l}3^{\text {rd }} \text { "The meaning of life as } \\
\text { a mechanism of spiritual } \\
\text { care enables a humanized } \\
\text { care and, especially, self- } \\
\text { knowledge to identify } \\
\text { what lead us to do what } \\
\text { we do and the degree } \\
\text { of importance of giving } \\
\text { meaning to life and to the } \\
\text { nursing practice". }\end{array}$ & $\begin{array}{l}\text { On that thought, students reported } \\
\text { that humanized care encompasses } \\
\text { all dimensions of human existence: } \\
\text { physical, psychological, social and } \\
\text { spiritual; and that knowing the meaning } \\
\text { of life is an opportunity to reflect and to } \\
\text { know the personal limits and fears and } \\
\text { promotes better attitudes concerning } \\
\text { the challenges of caring. }\end{array}$ \\
\hline
\end{tabular}

Finally, students affirmed that, as human beings, they go through several difficult situations that may cause them to give up of disciplines, academic semesters or academic studies in the challenges of their own lives. However, they reported that developing their spirituality and thus seek the meaning of life, would help them be more resilient and find self-help strategies, and, therefore, having a personal meaning is needed to help the patients seek their own meaning.

At the end of the class, students proposed that the topics spirituality and meaning of life could be addressed in a compulsory subject in the nursing curriculum and not as an elective discipline, since they felt privileged to have an opportunity to reflect and construct knowledge related to the theme proposed and the care practice.

\section{Study limitations}

The limitation of the study is the fact that it was developed only with a group of students, and its applicability in other faculties and students of the health field would be useful to ensure its effectiveness.

\section{Contributions to the nursing field}

This study will be able to offer a methodological and conceptual strategy to be used in the field of higher education in nursing, since it affords an opportunity for introspection and personal reflection on the importance of finding a meaning for life and profession. Addressing this topic with future health professionals can bring better personal perspectives and options for further care practice.

\section{FINAL CONSIDERATIONS}

One is a caregiver when caring, student when studying and teacher when teaching, but the difference in the way to perform or take a specific role or activity lies in the meaning given to it. One thing is to perform an activity such as caring due to compromise, duty, obligation or imposition, and quite another is to perform it because you find a meaning in it that provides personal and intellectual satisfaction. Having a meaning of life helps in keeping the psyche in homeostasis in moments of greater pressure and conflict. Finding a meaning in life increases the possibilities for understanding human existence, justifies what is done and enables creating better strategies to face the challenges posed by a given activity.

With the feedback from the shared teaching, students expressed a sum of knowledge about the meaning of life and, especially, feelings of hope regarding the profession, to the extent that caring for others can provide meaning and purpose of life as caregivers, as well as the possibility of addressing this theme along with the patient as an instrument of spiritual care.

The teaching internship was considered a successful experience, as the theme proposed was essential for the theoretical-reflective construction about spirituality and meaning of life as a form of care that transcends technical procedures. Considering that the future professionals dedicate their lives to caring for those in situations of physical, mental and spiritual fragility requiring a holistic care, the topic addressed aims to contribute to the quality of life both of the patient and the health professional.

\section{FUNDING}

Fundação de Amparo à Pesquisa do Estado do Rio de Janeiro - FAPERJ.

\section{REFERENCES}

1. FrankI VE. Em busca de sentido. Petrópolis: Vozes; 1991

2. World Health Organization (WHO). Division of mental health and prevention of substance abuse. WHOQOL and spirituality, religiousness and personal beliefs (SRPB) [Internet]. Geneva:WHO; 1998 [cited 2018 Jun 17]. Available from: http://apps.who.int/iris/ 
bitstream/10665/70897/1/WHO_MSA_MHP_98.2_eng.pdf

3. Salviano MEM, Nascimento PDFS, Paula MA, Vieira CS, Frison SS, Maia MA, et al. Epistemology of nursing care: a reflection on its foundations. Rev Bras Enferm [Internet]. 2016;69(6):1172-7. doi: 10.1590/0034-7167-2016-0331

4. Ministério da Saúde (BR). HumanizaSUS: política nacional de humanização [Internet]. Brasília: Ministério da Saúde; 2003 [cited 2018 Jun 15]. Available from: http://bvsms.saude.gov.br/bvs/publicacoes/humanizaSus.pdf

5. Rocha RCNP, Pereira ER, Silva RMCRA. The spiritual dimension and the meaning of life in nursing care: phenomenological approach. REME Rev Min Enferm. 2018;22:e-1151. doi: 10.5935/1415-2762.20180082

6. Sutkevičiūtè M, Stančiukaitè M, Bulotienè G. Individual Meaning-Centered Psychotherapy for palliative cancer patients in Lithuania. A case report. Acta Med Litu. 2017;24(1):67-73. doi: 10.6001/actamedica.v24i1.3464

7. FrankI VE. A vontade de sentido: fundamentos e aplicações da logoterapia. São Paulo: Paulus; 2011.

8. Bezerra RS, Oliveira DS, Santos RRF, Morais AC, Merces MC, Andrade LM. O processo de enfermagem e a teoria de Travelbee no cuidado à criança hospitalizada. Rev Elet Gest Saúde. 2015 [cited 2018 Jun 10];6(Suppl 3):2151-61. Available from: https://dialnet.unirioja.es/descarga/ articulo/5560277.pdf

9. Spudeite, D. Elaboração do plano de ensino e do plano de aula [Internet]. Rio de Janeiro: Universidade Federal do Estado do Rio de Janeiro; 2014[cited 2018 May 15]. Available from: http://www2.unirio.br/unirio/cchs/eb/ELABORAODOPLANODEENSINOEDOPLANODEAULA.pdf

10. Paiva MR, Parente JR, Brandão IR, Queiroz AHB. Metodologias ativas de ensino-aprendizagem: revisão integrativa. Sanare [Internet]. 2016 [cited 2018 Jun 20];15(2):145-53. Available from: https://sanare.emnuvens.com.br/sanare/article/view/1049 